\title{
Molecular targeting of hepatocyte growth factor by an antagonist, NK4, in the treatment of rheumatoid arthritis
}

\author{
Sachi Tsunemi ${ }^{1}$, Tsuyoshi Iwasaki ${ }^{2 *}$, Sachie Kitano ${ }^{1}$, Kunio Matsumoto ${ }^{3}$, Misato Takagi-Kimura ${ }^{4}$, Shuji Kubo ${ }^{4}$,
} Tomoko Tamaoki ${ }^{4}$ and Hajime Sano ${ }^{1}$

\begin{abstract}
Introduction: Hepatocyte growth factor (HGF) is a potent proangiogenic molecule that induces neovascularization. The HGF antagonist, NK4, competitively antagonizes HGF binding to its receptor. In the present study, we determined the inhibitory effect of NK4 in a rheumatoid arthritis (RA) model using SKG mice.

Methods: Arthritis was induced in SKG mice by a single intraperitoneal injection of $\beta$-glucan. Recombinant adenovirus containing NK4 CDNA (AdCMV.NK4) was also injected intravenously at the time of or 1 month after $\beta$-glucan injection. Ankle bone destruction was examined radiographically. The histopathologic features of joints were examined using hematoxylin and eosin and immunohistochemical staining. Enzyme-linked immunosorbent assays were used to determine the serum levels of HGF, interferon $\gamma$ (IFN- $\gamma$, interleukin 4 (IL-4) and IL-17 production by $\mathrm{CD}^{+} \mathrm{T}$ cells stimulated with allogeneic spleen cells.

Results: The intravenous injection of AdCMV.NK4 into SKG mice suppressed the progression of $\beta$-glucan-induced arthritis. Bone destruction was also inhibited by NK4 treatment. The histopathologic findings of the ankles revealed that angiogenesis, inflammatory cytokines and RANKL expression in synovial tissues were significantly inhibited by NK4 treatment. Recombinant NK4 (rNK4) proteins inhibited IFN- $\gamma$, IL-4 and IL-17 production by CD4 ${ }^{+} \mathrm{T}$ cells stimulated with allogeneic spleen cells.

Conclusions: These results indicate that NK4 inhibits arthritis by inhibition of angiogenesis and inflammatory cytokine production by $\mathrm{CD}^{+} \mathrm{T}$ cells. Therefore, molecular targeting of angiogenic inducers by NK4 can potentially be used as a novel therapeutic approach for the treatment of RA.
\end{abstract}

Keywords: Adenovirus, Angiogenesis, Hepatocyte growth factor, Rheumatoid arthritis

\section{Introduction}

Rheumatoid arthritis (RA) is a chronic inflammatory disease which causes progressive deformity and destruction of the joints [1]. RA is characterized by aggressive synovial expansion and invasion and subsequent destruction of the underlying cartilage and bone. Synovial expansion is dependent on an adequate blood supply for nutrients and oxygen. New blood vessel formation (angiogenesis) is

\footnotetext{
* Correspondence: tsuyo-i@huhs.ac.jp

${ }^{2}$ Division of Pharmacotherapy, Department of Pharmacy, School of Pharmacy, Hyogo University of Health Sciences, 1-3-6 Minatojima, Chuo-ku, Kobe, 650-8530, Japan

Full list of author information is available at the end of the article
}

therefore critically important for the delivery of oxygen, nutrients and inflammatory cells to the lesions of RA $[2,3]$.

There is mounting evidence that angiogenic inducers, such as vascular endothelial growth factor (VEGF), play a pivotal role in RA [4-6]. The intravenous administration of adenovirus expressing sFlt-1, the secreted form of the extracellular domain of the Flt-1 VEGF receptor, in a collagen-induced arthritis (CIA) model results in blocking of VEGF receptor signaling and a reduction in joint swelling [7].

Hepatocyte growth factor (HGF) has angiogenic activity for vascular endothelial cells [8]. HGF has a role in the dynamic construction and reconstruction of normal tissues during organogenesis and tissue regeneration [9];
Ciomed Central

() 2013 Tsunemi et al.; licensee BioMed Central Ltd. This is an open access article distributed under the terms of the Creative Commons Attribution License (http://creativecommons.org/licenses/by/2.0), which permits unrestricted use, distribution, and reproduction in any medium, provided the original work is properly cited. 
however, tumor cells utilize the biological actions of HGF for dissociative, invasive and metastatic behavior [10]. The abrogation of HGF receptor (c-Met)-mediated signaling events appears to be a highly promising strategy for the prevention of tumor metastasis [11]. NK4 has been isolated as a competitive antagonist for HGF and the c-Met receptor [12], and subsequent studies have shown that NK4 also inhibits the angiogenic response induced by basic fibroblast growth factor (bFGF) and VEGF [13].

In the present study, we utilized adenovirus expressing the NK4 gene, which has previously been demonstrated to suppress tumor growth and vascularization in mice [14]. Our data demonstrate that adenoviral delivery of NK4 gene significantly suppresses disease activity in a model of RA in SKG mice.

\section{Materials and methods Mice}

Female SKG mice [15-17], 7 to 8 weeks old, were purchased from CLEA Japan (Tokyo, Japan) and maintained under specific pathogen-free conditions in the animal facility of the Hyogo College of Medicine (Nishinomiya, Hyogo, Japan). Female C57BL/6 (B6) mice, 8 to 12 weeks old, were purchased from the Shizuoka Laboratory Animal Center (Shizuoka, Japan). Animal experiments were conducted in accordance with the guidelines of the National Institutes of Health (Bethesda, MD, USA), as specified by the animal care policy of Hyogo College of Medicine. All of the experimental procedures were reviewed and approved by the Animal Care and Use Committee of Hyogo College of Medicine.

\section{Clinical assessment of SKG arthritis}

Arthritis was induced by a single intraperitoneal injection of the $\beta$-glucan laminarin (45 mg). Joint swelling was monitored by inspection and scored as follows: 0 , no swelling; 0.1 , swelling of one toe joint; 0.5 , mild ankle swelling; and 1.0, severe ankle swelling. The scores for all toes and ankles were totaled for each mouse. The ankle volume was measured with a water replacement plethysmometer (Unicom Japan, Tokyo, Japan).

\section{Preparation and measurement of NK4}

AdCMV.NK4 and AdCMV.LacZ are structurally similar replication-deficient recombinant adenovirus type 5 (Ad5)-based vectors with E1 and E3 deletions in which the NK4 gene and $L a c Z$ transgene, respectively, are under transcriptional control of the cytomegalovirus (CMV) immediate-early enhancer and promoter. The recombinant virus vectors were grown in HEK-293 cells and twice purified by $\mathrm{CsCl}$ gradient centrifugation, and titers were determined by serial dilution end point assay. All vectors were free of replication-competent adenovirus [18]. NK4 in serum was determined using an enzyme-linked immunosorbent assay (ELISA) kit for human HGF (Funakoshi Co, Tokyo, Japan). All work was performed in accordance with an approved protocol from the Institutional Biosafety Committee of Hyogo College of Medicine.

\section{Histopathology and immunohistochemistry}

Joints were fixed in 10\% formalin, decalcified using $10 \%$ ethylenediaminetetraacetic acid in phosphate-buffered saline (PBS) for 3 days, embedded in paraffin, sectioned and stained with hematoxylin and eosin. Microscopic examinations of the joints were conducted with subjective grading of inflammatory cell infiltration, synovial hyperplasia and cartilage and bone destruction. Joint grading was as follows [19]: normal, mild (minimum inflammatory cell infiltration and synovial hyperplasia with some cartilage loss), moderate (more extensive inflammatory cell infiltration and synovial hyperplasia with considerable bone erosion) and severe (complete destruction of joint architecture). All analyses were performed in a blinded fashion by an observer who was unaware of the clinical status of the animal. For immunohistochemical staining, cryostat sections of joints were fixed in cold acetone for $10 \mathrm{~min}$, washed in PBS and depleted of endogenous peroxidase by treatment with $0.3 \% \mathrm{H}_{2} \mathrm{O}_{2}$ in absolute methanol for $15 \mathrm{~min}$. After blocking nonspecific binding with $10 \%$ normal rabbit serum in PBS for $30 \mathrm{~min}$, the sections were incubated with anti-mouse interleukin 6 antibody (IL-6 Ab; goat immunoglobulin G (IgG)), anti-mouse tumor necrosis factor $\alpha$ (TNF- $\alpha$ ) Ab (goat IgG), anti-mouse CD31 Ab (goat IgG), anti-RANKL (anti-receptor activator of nuclear factor $\kappa \mathrm{B}$ ligand) $\mathrm{Ab}$ (goat IgG), anti-mouse IL$17 \mathrm{Ab}$ (goat IgG; all from Santa Cruz Biotechnology, Santa Cruz, CA, USA), anti-mouse IL-1 Ab (goat IgG; R\&D Systems, Minneapolis, MN, USA), anti-mouse HGF $\mathrm{Ab}$ (rabbit IgG) or anti-mouse c-Met Ab (rabbit IgG) at appropriate dilutions for $1 \mathrm{~h}$ at room temperature, washed, incubated with biotinylated goat anti-rabbit IgG, washed again and incubated with avidin-biotinylated horseradish peroxidase complex $(\mathrm{ABC})$ and 3,3'-diaminobenzidine tetrahydrochloride (DAB) (VECTASTAIN Elite $\mathrm{ABC}$ Kit; Vector Laboratories, Burlingame, CA, USA) and counterstained with Mayer's hematoxylin. MH7A cells and synovial tissue specimens isolated from patients with RA and osteoarthritis (OA) at the time of arthroscopic biopsy or total joint replacement were stained as reported previously [20]. Briefly, synovial tissues were stained with anti-human HGF Ab (rabbit IgG) or anti-human c-Met Ab (rabbit IgG), washed, incubated with biotinylated goat anti-rabbit IgG, washed again, incubated with $A B C$ and $D A B$ and counterstained with Mayer's hematoxylin. All patients gave their informed 
consent to participate, and the Institutional Medical Ethics Committee approved the study protocol.

\section{Mixed lymphocyte reaction and in vitro cytokine production}

The mixed lymphocyte reaction was performed as described previously $[21,22]$. Briefly, $\mathrm{CD}_{4}^{+} \mathrm{T}$ cells and CD11 $\mathrm{c}^{+}$dendritic cells (DCs) were purified from spleens using immunomagnetic beads (Miltenyi Biotec, Auburn, CA, USA). The purity of the $\mathrm{CD}_{4}^{+}$and $\mathrm{CD} 11 \mathrm{c}^{+}$populations was greater than $95 \%$ and more than $90 \%$, respectively. DCs from C57BL/6 mice (H-2 ${ }^{\text {b }} ; 1 \times 10^{6}$ cells $/ \mathrm{ml} /$ well) were incubated in the presence or absence of HGF or NK4 for $24 \mathrm{~h}$. After thrice washing with Hanks' balanced salt solution (HBSS), DCs were irradiated (20 Gy) and cocultured with CD4 ${ }^{+} \mathrm{T}$ cells from SKG mice $\left(\mathrm{H}-2^{\mathrm{d}} ; 4 \times 10^{6} \mathrm{cells} / \mathrm{ml} /\right.$ well $)$ in 24-well flat-bottomed plates (Falcon Labware, Lincoln Park, NJ, USA). After $72 \mathrm{~h}$, viable cells were harvested, and, after thrice washing with HBSS, the cells $\left(1 \times 10^{5}\right.$ cells $/ 200 \mu \mathrm{l} /$ well $)$ were stimulated in 96-well flat-bottomed plates (Falcon Labware) coated with $5 \mu \mathrm{g} / \mathrm{ml}$ anti-mouse CD3 mAb. After $48 \mathrm{~h}$, interferon $\gamma$ (IFN)- $\gamma$, IL-4 and IL-17 concentrations in the culture supernatants were measured by ELISA using antimouse IFN- $\gamma$, IL-4 and IL-17 mAbs, respectively (Genzyme, Cambridge, MA, USA), according to the manufacturer's protocol.

\section{Serum HGF ELISA}

The serum HGF levels in SKG mice were measured by ELISA using anti-mouse HGF mAb (R\&D Systems) according to the manufacturer's protocol.

\section{Bone X-ray}

The ankles were examined radiographically after the mice were killed by $\mathrm{CO}_{2}$ inhalation on day $60 . \mathrm{X}$-ray images of the ankles were obtained with an X-ray apparatus ( $\mu$ FX-1000; FUIIFILM, Tokyo, Japan) using the following settings: $100 \mathrm{kV}, 40 \mu \mathrm{A}$ and 7-s exposure time.

\section{Statistics}

Student's $t$-test was used for statistical analysis.

\section{Results}

AdCMV.NK4 induces NK4 proteins in SKG mice in vivo To verify the in vivo production of NK4 protein after AdCMV.NK4 injection, AdCMV.NK4 $\left(1 \times 10^{9}\right.$ plaqueforming units (pfu)) was injected intravenously into SKG mice. We observed significantly elevated levels of NK4 protein in the blood 1 day after injection (Figure 1A). Systemically administered adenoviruses are scavenged by the reticuloendothelial system (primarily in the liver) [23]. We also observed the expression of NK4 protein in the liver by immunohistochemistry 1 day after injection (Figure 1B).

\section{HGF and c-Met expression in the synovia of SKG mice and RA patients}

To examine whether the HGF/c-Met pathway is involved in the pathogenesis of RA, we first determined the expression of HGF and c-Met in the synovia of SKG mice. In SKG mice, joint swelling began to develop in a few digits approximately 1 month after $\beta$-glucan injection, subsequently progressing to other digits and to larger joints (wrists and ankles) in a symmetric fashion. Immunohistochemical staining of synovial tissues 2 months after $\beta$-glucan injection revealed high expression of c-Met in the synovial lining and vascular cells. HGF was also expressed in the synovial lining and fibroblastic cells (Figure 2A). The serum levels of HGF in arthritisinduced SKG mice were higher than in untreated SKG mice (Figure 2B). We next examined the expression of c-Met and HGF in the synovium. c-Met expression in mononuclear cells, blood vessels and synovial lining cells of RA patients was higher than in OA patients. HGF was expressed in the synovial lining and fibroblastic cells of RA and OA synovial tissues (Figure 2C).

\section{AdCMV.NK4 reduces clinical score and joint swelling in SKG mice}

To determine whether NK4 inhibited joint swelling, AdCMV.NK4 $\left(1 \times 10^{9} \mathrm{pfu}\right)$, or AdCMV.LacZ $\left(1 \times 10^{9} \mathrm{pfu}\right)$ as a control, was administered intravenously to the mice from the time of $\beta$-glucan injection. Joint swelling of the AdCMV.LacZ-treated SKG mice began on day 32 after $\beta$-glucan injection and progressed significantly on day 75 . In contrast, mice that received AdCMV.NK4 had less joint swelling as determined by the clinical score (Figure 3A) and ankle volume (Figure 3B) 60 days following $\beta$-glucan injection. In clinical situations, gene therapy is more likely to be used therapeutically than to prevent disease. To determine the therapeutic effectiveness of this treatment on arthritis, we introduced AdCMV.NK4 $\left(1 \times 10^{9} \mathrm{pfu}\right)$ into SKG mice 1 month after $\beta$-glucan injection. SKG mice that received AdCMV.NK4 had less joint swelling than control mice that received AdCMV.LacZ 60 days following $\beta$-glucan injection (Figure $3 \mathrm{C}$ ).

\section{AdCMV.NK4 reduces histopathologic changes in SKG mice}

The histopathologic features of swollen joints in AdCMV.LacZ-treated SKG mice, as shown by hematoxylin and eosin staining, included vigorous proliferation of synovial cells and infiltration of synovial tissues by mononuclear cells and neutrophils, which has been observed in human RA [1]. In contrast, these pathologic changes were significantly inhibited in NK4-treated SKG mice. 


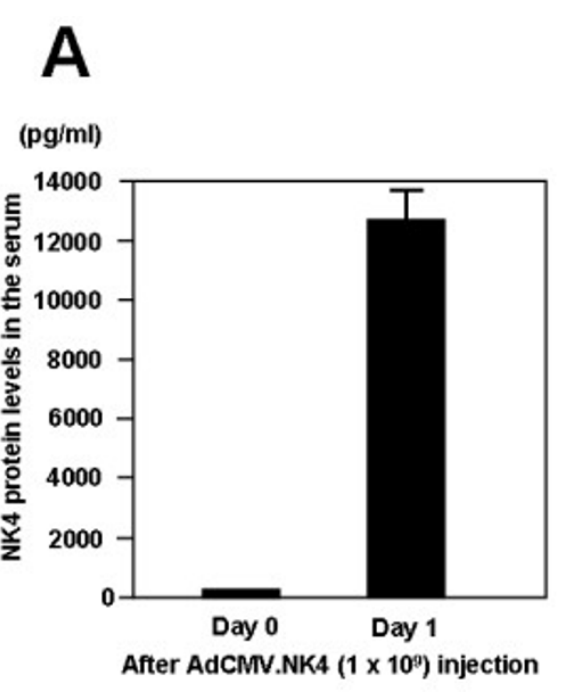

\section{B}

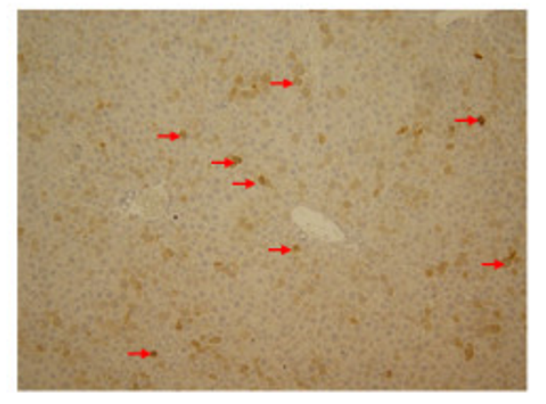

Figure 1 AdCMV.NK4 induces NK4 protein in SKG mice. SKG mice were injected intravenously with AdCMV.NK4 $\left(1 \times 10^{9}\right.$ plaque-forming units (pfu)) into the tail vein. One day after injection, serum and liver were obtained and NK4 protein levels in the serum (A) and NK4 protein expression in the liver (B) were measured by hepatocyte growth factor (HGF) enzyme-linked immunosorbent assay (ELISA) or immunohistochemistry, respectively. Data in $(A)$ are represented as the means \pm SD $(n=6)$. The arrows in (B) represent NK4 protein expression in hepatocytes. Original magnification, $\times 100$.

X-ray examination of the ankle joints 60 days following $\beta$-glucan injection of AdCMV.LacZ-treated SKG mice revealed erosion of the cartilage and subchondral bone, whereas these changes were inhibited in NK4-treated SKG mice (Figure 4).
AdCMV.NK4 reduces inflammatory cell infiltration, as well as cytokine and RANKL expression, in synovial tissue Immunohistochemical staining of synovial tissues from AdCMV.LacZ-treated SKG mice revealed high expression of IL-1, IL- 6 and TNF- $\alpha$. In contrast, AdCMV.

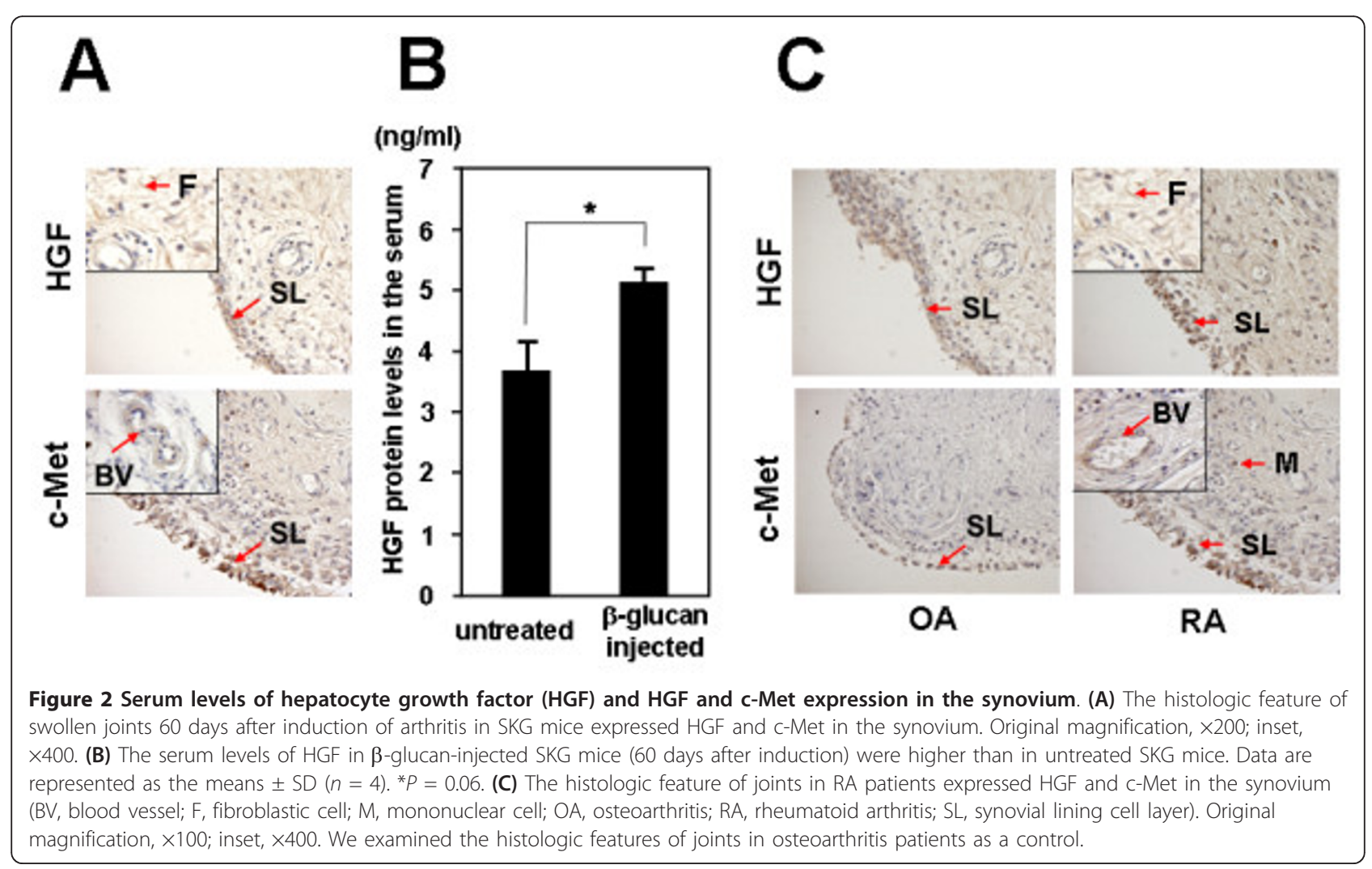




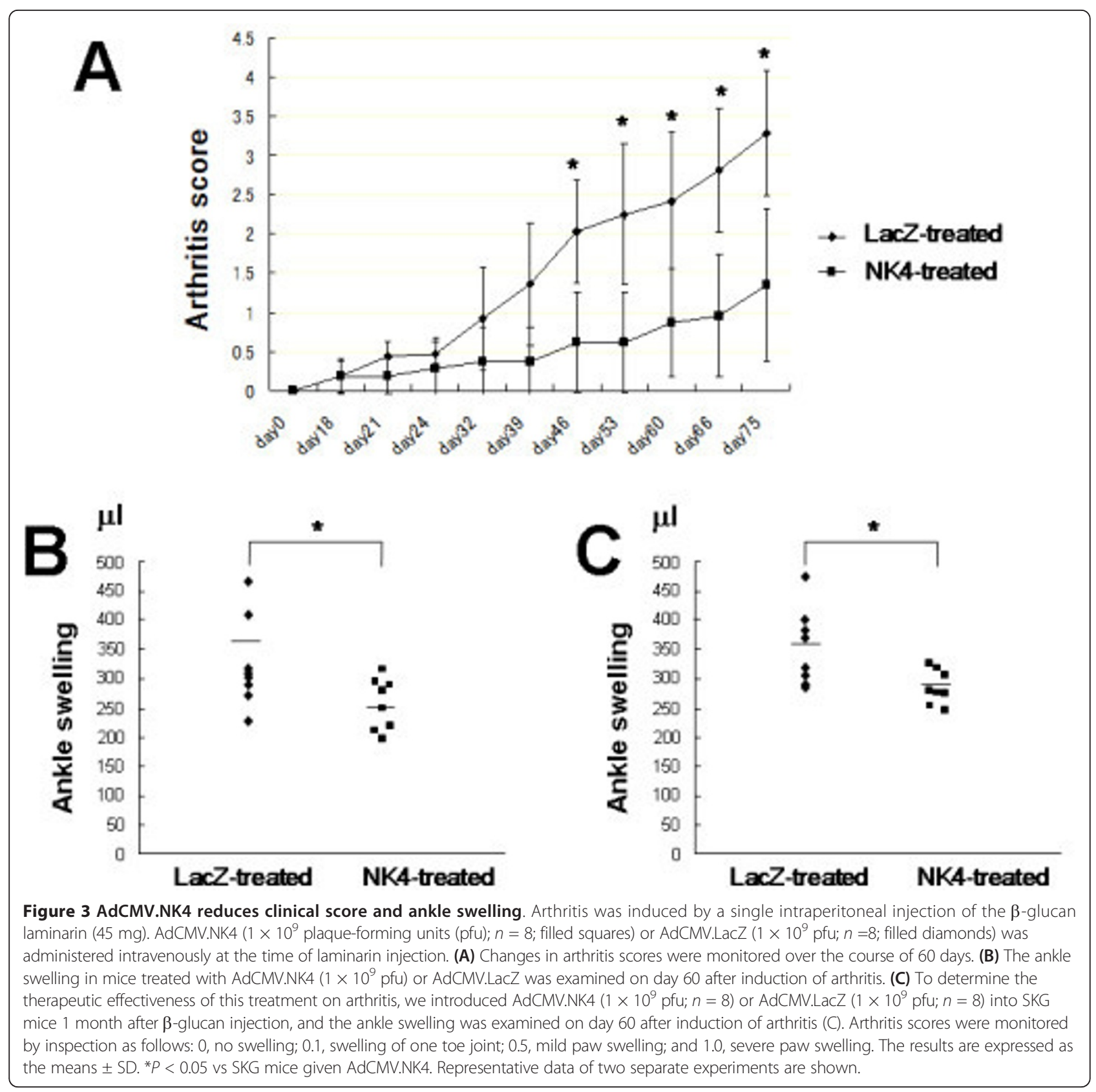

NK4-treated SKG mice did not express these cytokines AdCMV.NK4 treatment also inhibited type 17 T-helper (Th17) cell infiltration and RANKL expression in the synovial tissues (Figure 5).

Recombinant NK4 inhibits interferon $\gamma$, interleukin 4 and interleukin 17 production by $\mathrm{CD}^{+} \mathrm{T}$ cells in vitro

We examined the effect of recombinant NK4 (rNK4) on the production of IFN- $\gamma$, IL- 4 and IL- 17 by CD4 $4^{+}$T cells stimulated with allogeneic DCs. CD $11 \mathrm{c}^{+}$DCs from C57BL/6 mice were preincubated in the presence or absence of HGF or NK4 for 24 h. CD $^{+}{ }^{+} \mathrm{T}$ cells from
SKG mice were cultured with irradiated CD11c ${ }^{+}$DCs, and IFN- $\gamma$, IL-4 and IL-17 production in culture supernatants was measured by ELISA. Preincubation of rNK4 and HGF inhibited IFN- $\gamma$, IL-4 and IL-17 production by $\mathrm{CD}^{+} \mathrm{T}$ cells (Figure 6).

\section{Discussion}

We have demonstrated that the HGF antagonist NK4 significantly suppresses arthritis in a SKG mouse model, as demonstrated by the ankle volume and arthritis score. It has been reported that HGF is expressed in synovial tissues and that vascular endothelial cells 


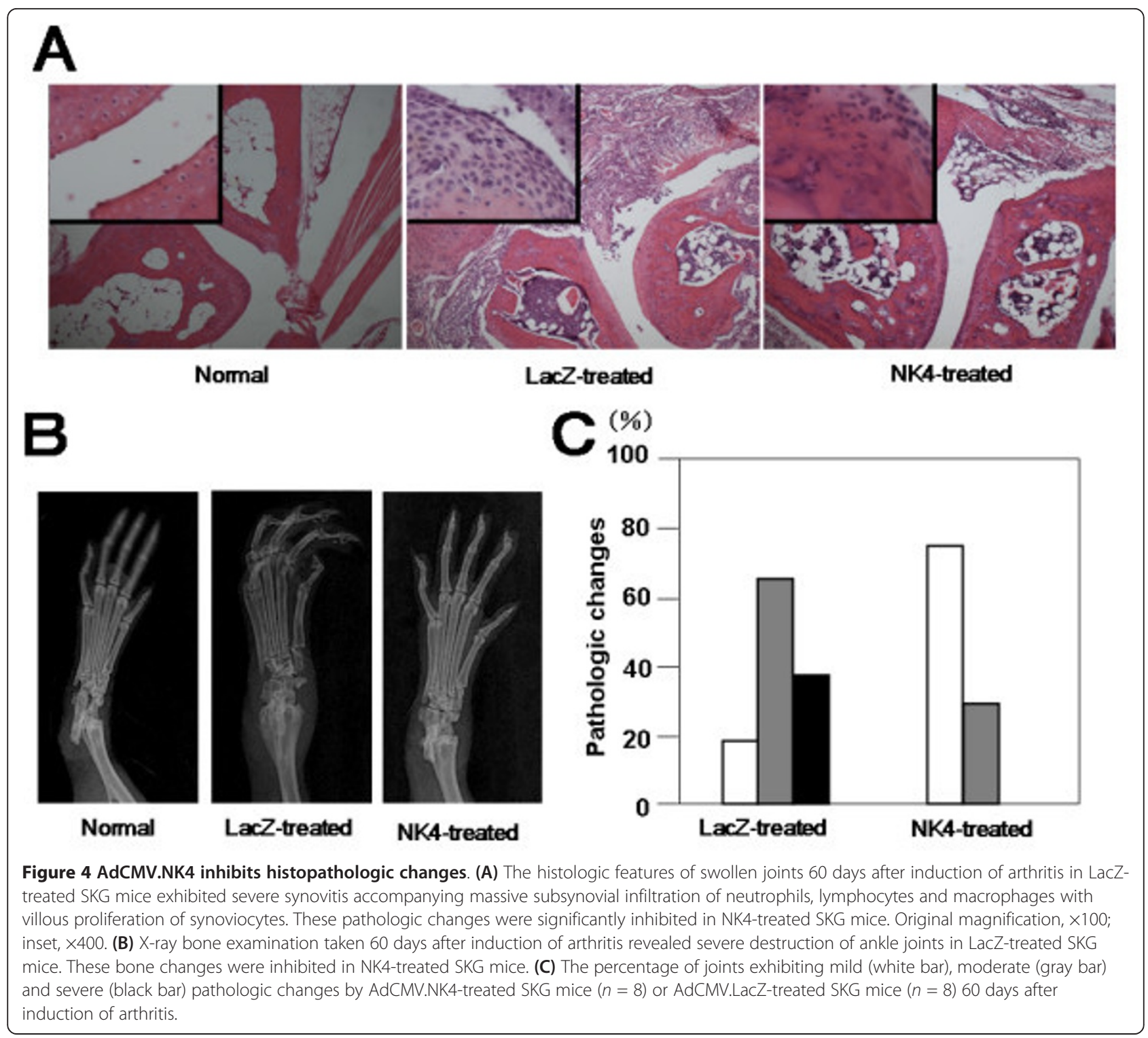

express c-Met in patients with RA [24]. Synovial fluid HGF in patients with RA is produced by synovial cells and is related to disease activity [25]. We also demonstrated that HGF is expressed in synovial lining cells, and c-Met is strongly expressed in mononuclear, vascular endothelial and synovial lining cells of RA patients. These results suggest that NK4 inhibits angiogenesis induced by HGF-c-Met signaling in synovial tissues of patients with RA.

NK4 is a proteolytic fragment of HGF, consisting of an $\mathrm{N}$-terminal hairpin domain and four kringle domains of the $\alpha$ chain of HGF [12]. The NK4 fragment appears to be generated by mast cell and neutrophil peptidases under physiologic and pathologic conditions such as inflammation and cancer, thus regulating angiogenesis [26]. In addition to antagonizing HGF by competitively binding to
c-Met, NK4 inhibits the angiogenic responses of endothelial cells induced by bFGF and VEGF [13], suggesting that new binding molecules of NK4 other than c-Met may exist, such as perlecan, the major extracellular heparan sulfate proteoglycans associated with blood vessels as previously reported [27].

The systemic administration of AdCMV.NK4 induced the production of significant NK4 protein in the blood and liver 1 day after administration. Adenoviral vectors have particular advantages for use as in vivo gene transfer vehicles, including a broad host range, the ability to infect both dividing and nondividing cells and the ease of hightiter purification [28]. Studies using adenovirus encoding for inflammatory cytokines or their receptors, such as TNF receptor p55, IL-4 and IL-10 in CIA have been reported [29-31]. Administration of adenovirus expressing 


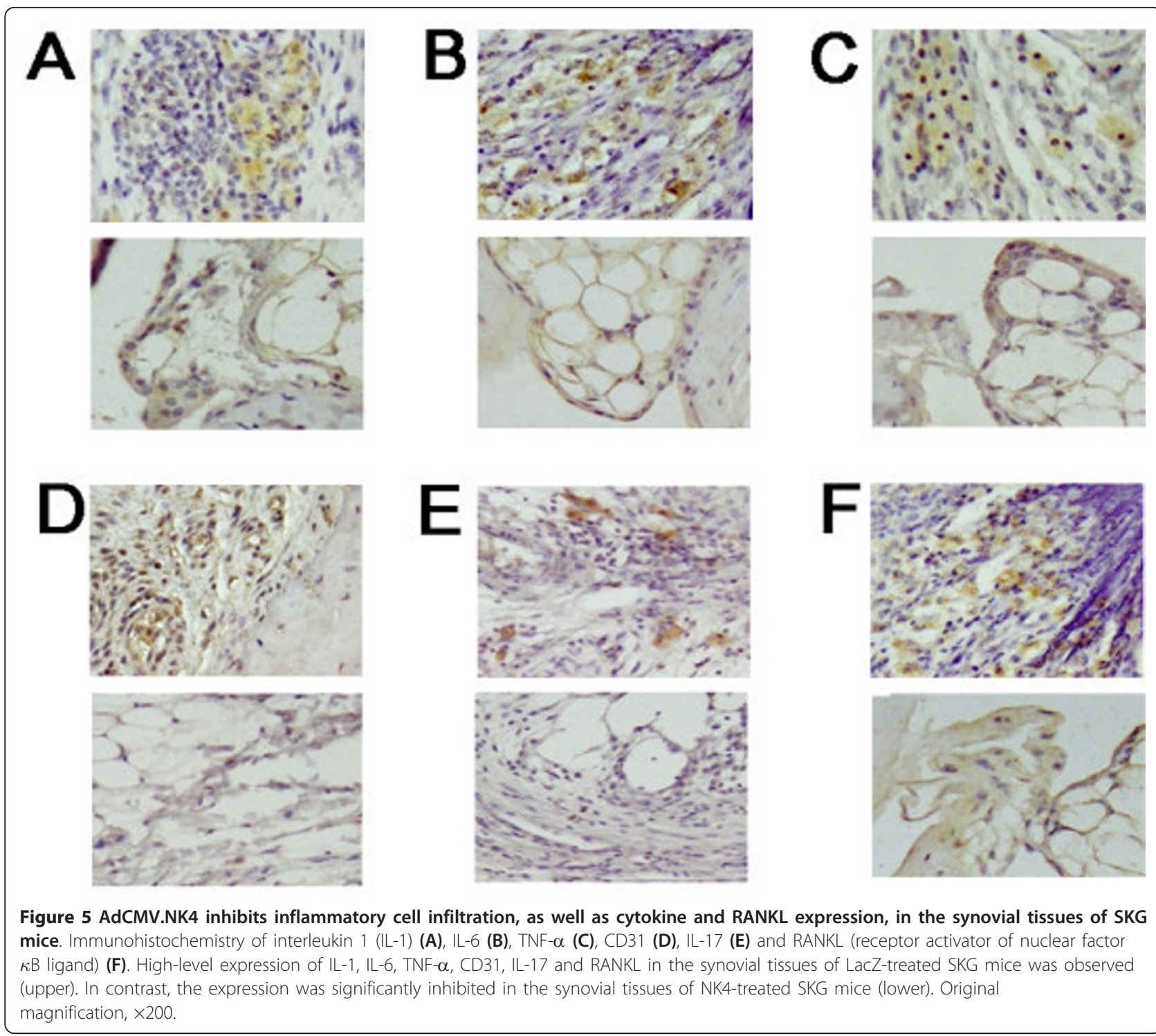

Flt-1 was also able to suppress clinical scores, ankle swelling and joint destruction [7]. sFlt-1 expression was demonstrated in systemic and effecter regions, although the expression was transient because of antibody responses targeting the adenovirus and human transgene. We also measured NK4 protein in serum by ELISA using anti-human HGF antibody. In mice receiving $1 \times 10^{9} \mathrm{pfu}$ of Ad.CMV.NK4 via the tail vein, NK4 protein in serum peaked at more than $1,300 \mathrm{pg} / \mathrm{ml} 24 \mathrm{~h}$ after transduction, then gradually declined to $0 \mathrm{ng} / \mathrm{ml} 14$ days after transduction (data not shown). These results suggest that shortterm blockage of angiogenesis in the early phase of arthritis inhibits arthritis in SKG mice. To determine the therapeutic effectiveness of this treatment on arthritis, we introduced AdCMV.NK4 $\left(1 \times 10^{9} \mathrm{pfu}\right)$ into SKG mice 1 month after $\beta$-glucan injection. SKG mice that received AdCMV.
NK4 had less joint swelling than control mice that received AdCMV.LacZ 60 days following $\beta$-glucan injection.

Presentation of antigen by antigen-presenting cells (APCs) to $\mathrm{T}$ cells initiates the differentiation of naïve Th cells into effector T cells. The expression of costimulatory molecules on APCs and the cytokine profile produced by APCs play a critical role during the differentiation into each T-cell phenotype, such as Th1, Th2 or regulatory $\mathrm{T}$ (Treg) cells [32]. DCs are the most efficient and crucial APCs [33]. Recent studies have reported the effect of HGF on DC function [34,35]. Rutella et al. [35] reported that, in in vitro experiments, HGF suppresses alloantigen-presenting capacity, modulates costimulatory molecule expression and cytokine production of DCs and generates DCs that induce Treg cells. Okunishi et al. [34] reported that HGF potently suppresses antigen-presenting capacity and 


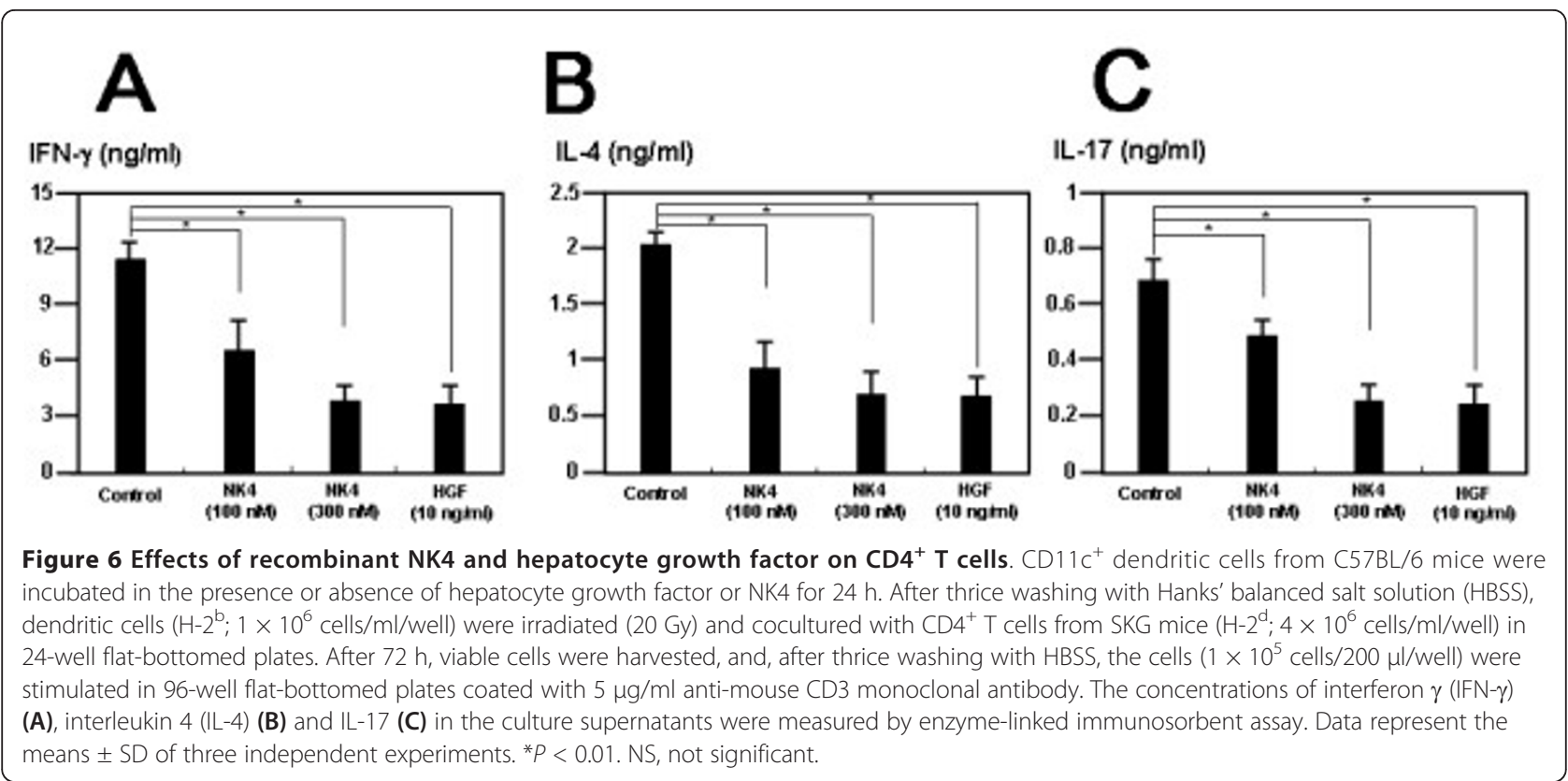

IL-12p70 production of DCs, thus inhibiting development of Th1- and Th2-type immune responses induced by ovalbumin. Okunishi et al. [36] also demonstrate that HGF potently inhibits the development of CIA with augmentation of the Th2-type immune response and suppression of IL-17 production. Because NK4 antagonizes HGF, it is thought that NK4 inhibits immune responses induced by HGF. In contrast, AdCMV.NK4 inhibited inflammatory cytokine expression in synovial tissues of SKG mice. In addition, rNK4 inhibited IFN- $\gamma$, IL-4 and IL-17 production from the $\mathrm{CD}^{+} \mathrm{T}$ cells stimulated with allogeneic spleen cells. Although the precise mechanisms by which NK4 inhibits inflammatory responses are not clear, it is possible that new binding molecules of NK4 on DCs may exert these functions after binding to NK4.

\section{Conclusions}

Our results demonstrate that systemic administration of AdCMV.NK4 inhibits synovial cell proliferation and inflammatory responses in the joints of SKG mice in a RA model. We have also demonstrated that NK4 inhibits inflammatory cytokine production by $\mathrm{CD}_{4}^{+} \mathrm{T}$ cells. The data indicate the potential utility of NK4 in the treatment for RA.

\footnotetext{
Abbreviations

APC: antigen-presenting cell; bFGF: basic fibroblast growth factor; CIA: collagen-induced arthritis; CMV: cytomegalovirus; DC: dendritic cell; HGF: hepatocyte growth factor; MMP-3: matrix metalloproteinase 3; OA: osteoarthritis; RA: rheumatoid arthritis; VEGF: vascular endothelial growth factor
}

\section{Competing interests}

The authors declare that they have no competing interests.

\section{Authors' contributions}

All authors were involved in drafting the manuscript or revising the manuscript critically, and all authors approved the final version of the manuscript for publication. ST and SK performed all of the experiments and analyzed the data. TI and HS designed the experiments and take responsibility for the accuracy of the data analysis. KM provided the AdCMV. NK4 and AdCMV.LacZ vectors. TT, SK and MTK prepared the AdCMV.NK4 and AdCMV.LacZ vectors.

\section{Acknowledgements}

The expert technical help of Takehito Imado is gratefully acknowledged. This work was supported by a Grant-in-Aid for Exploratory Research from the Ministry of Education, Science and Culture of Japan (21590187).

\section{Authors' details}

'Division of Rheumatology, Department of Internal Medicine, Hyogo College of Medicine, 1-1 Mukogawa-cho, Nishinomiya, Hyogo 663-8501, Japan. ${ }^{2}$ Division of Pharmacotherapy, Department of Pharmacy, School of Pharmacy, Hyogo University of Health Sciences, 1-3-6 Minatojima, Chuo-ku, Kobe, 650-8530, Japan. ${ }^{3}$ Division of Tumor Dynamics and Regulation, Cancer Research Institute, Kakuma-cho, Kanazawa, Ishikawa 920-1192, Japan. ${ }^{4}$ Department of Genetics, Hyogo College of Medicine, 1-1 Mukogawa-cho, Nishinomiya, Hyogo 663-8501, Japan.

Received: 18 July 2012 Accepted: 22 July 2013 Published: 22 July 2013

\section{References}

1. Scott DL, Wolfe F, Huizinga TW: Rheumatoid arthritis. Lancet 2010, 376:1094-1108.

2. Szekanecz Z, Koch AE: Vascular involvement in rheumatic diseases: 'vascular rheumatology'. Arthritis Res Ther 2008, 10:224.

3. Szekanecz Z, Besenyei T, Szentpétery A, Koch AE: Angiogenesis and vasculogenesis in rheumatoid arthritis. Curr Opin Rheumatol 2010, 22:299-306.

4. Koch AE, Harlow LA, Haines GK, Amento EP, Unemori EN, Wong WL, Pope RM, Ferrara N: Vascular endothelial growth factor: a cytokine modulating endothelial function in rheumatoid arthritis. J Immunol 1994, 152:4149-4156.

5. Paleolog EM, Young S, Stark AC, McCloskey RV, Feldmann M, Maini RN: Modulation of angiogenic vascular endothelial growth factor by tumor necrosis factor a and interleukin-1 in rheumatoid arthritis. Arthritis Rheum 1998, 41:1258-1265. 
6. Fava RA, Olsen NJ, Spencer-Green G, Yeo KT, Yeo TK, Berse B, Jackman RW, Senger DR, Dvorak HF, Brown LF: Vascular permeability factor/endothelial growth factor (VPF/VEGF): accumulation and expression in human synovial fluids and rheumatoid synovial tissue. J Exp Med 1994, 180:341-346.

7. Afuwape $A O$, Feldmann M, Paleolog EM: Adenoviral delivery of soluble VEGF receptor 1 (sFlt-1) abrogates disease activity in murine collageninduced arthritis. Gene Ther 2003, 10:1950-1960.

8. Bussolino F, Di Renzo MF, Ziche M, Bochietto E, Olivero M, Naldini L, Gaudino G, Tamagnone L, Coffer A, Comoglio PM: Hepatocyte growth factor is a potent angiogenic factor which stimulates endothelial cell motility and growth. J Cell Biol 1992, 119:629-641.

9. Nakamura T, Nishizawa T, Hagiya M, Seki T, Shimonishi M, Sugimura A, Tashiro K, Shimizu S: Molecular cloning and expression of human hepatocyte growth factor. Nature 1989, 342:440-443.

10. Birchmeier C, Birchmeier W, Gherardi E, Vande Woude GF: Met, metastasis, motility and more. Nat Rev Mol Cell Biol 2003, 4:915-925.

11. Matsumoto K, Nakamura T, Sakai K, Nakamura T: Hepatocyte growth factor and Met in tumor biology and therapeutic approach with NK4. Proteomics 2008, 8:3360-3370.

12. Date $K$, Matsumoto $K$, Shimura H, Tanaka M, Nakamura T: HGF/NK4 is a specific antagonist for pleiotrophic actions of hepatocyte growth factor. FEBS Lett 1997, 420:1-6.

13. Kuba K, Matsumoto K, Date K, Shimura H, Tanaka M, Nakamura T: HGF/NK4, a four-kringle antagonist of hepatocyte growth factor, is an angiogenesis inhibitor that suppresses tumor growth and metastasis in mice. Cancer Res 2000, 60:6737-6743.

14. Martin TA, Parr C, Davies G, Watkins G, Lane J, Matsumoto K, Nakamura T, Mansel RE, Jiang WG: Growth and angiogenesis of human breast cancer in a nude mouse tumour model is reduced by NK4, a HGF/SF antagonist. Carcinogenesis 2003, 24:1317-1323.

15. Sakaguchi N, Takahashi T, Hata H, Nomura T, Tagami T, Yamazaki S, Sakihama T, Matsutani T, Negishi I, Nakatsuru S, Sakaguchi S: Altered thymic T-cell selection due to a mutation of the ZAP-70 gene causes autoimmune arthritis in mice. Nature 2003, 426:454-460.

16. Hata H, Sakaguchi N, Yoshitomi H, Iwakura $Y$, Sekikawa $Y$, Azuma $Y$, Kanai C, Moriizumi E, Nomura T, Nakamura T, Sakaguchi S: Distinct contribution of IL-6, TNF-a, IL-1, and IL-10 to T cell-mediated spontaneous autoimmune arthritis in mice. J Clin Invest 2004, 114:582-588.

17. Yoshitomi H, Sakaguchi N, Kobayashi K, Brown GD, Tagami T, Sakihama T, Hirota K, Tanaka S, Nomura T, Miki I, Gordon S, Akira S, Nakamura T, Sakaguchi S: A role for $\beta$-glucans and their receptor dectin-1 in the induction of autoimmune arthritis in genetically susceptible mice. J Exp Med 2005, 201:949-960.

18. Maemondo M, Narumi K, Saijo Y, Usui K, Tahara M, Tazawa R, Hagiwara K, Matsumoto K, Nakamura T, Nukiwa T: Targeting angiogenesis and HGF function using an adenoviral vector expressing the HGF antagonist NK4 for cancer therapy. Mol Ther 2002, 5:177-185.

19. Tsunemi S, Iwasaki T, Kitano S, Imado T, Miyazawa K, Sano H: Effects of the novel immunosuppressant FTY720 in a murine rheumatoid arthritis model. Clin Immunol 2010, 136:197-204.

20. Kitano M, Hla T, Sekiguchi M, Kawahito Y, Yoshimura R, Miyazawa K, Iwasaki T, Sano H: Sphingosine 1-phosphate/sphingosine 1-phosphate receptor 1 signaling in rheumatoid synovium: regulation of synovial proliferation and inflammatory gene expression. Arthritis Rheum 2006, 54:742-753.

21. Kuroiwa T, Iwasaki T, Imado T, Sekiguchi M, Fujimoto J, Sano H: Hepatocyte growth factor prevents lupus nephritis in a murine lupus model of chronic graft-versus-host disease. Arthritis Res Ther 2006, 8:R123.

22. Iwasaki T, Imado T, Kitano S, Sano H: Hepatocyte growth factor ameliorates dermal sclerosis in the tight-skin mouse model of scleroderma. Arthritis Res Ther 2006, 8:R161.

23. Shayakhmetov DM, Li ZY, Ni S, Liber A: Analysis of adenovirus sequestration in the liver, transduction of hepatic cells, and innate toxicity after injection of fiber-modified vectors. J Virol 2004, 78:5368-5381.

24. Nagashima M, Hasegawa J, Kato K, Yamazaki J, Nishigai K, Ishiwata T, Asano G, Yoshino S: Hepatocyte growth factor (HGF), HGF activator, and c-Met in synovial tissues in rheumatoid arthritis and osteoarthritis. J Rheumatol 2001, 28:1772-1778.
25. Yukioka K, Inaba M, Furumitsu Y, Yukioka M, Nishino T, Goto H, Nishizawa Y, Morii $\mathrm{H}$ : Levels of hepatocyte growth factor in synovial fluid and serum of patients with rheumatoid arthritis and release of hepatocyte growth factor by rheumatoid synovial fluid cells. J Rheumatol 1994, 21:2184-2189.

26. Raymond WW, Cruz AC, Caughey GH: Mast cell and neutrophil peptidases attack an inactivation segment in hepatocyte growth factor to generate NK4-like antagonists. J Biol Chem 2006, 281:1489-1494

27. Sakai K, Nakamura T, Matsumoto K, Nakamura T: Angioinhibitory action of NK4 involves impaired extracellular assembly of fibronectin mediated by perlecan-NK4 association. J Biol Chem 2009, 284:22491-22499.

28. Kubo S, Mitani K: A new hybrid system capable of efficient lentiviral vector production and stable gene transfer mediated by a single helperdependent adenoviral vector. J Virol 2003, 77:2964-2971.

29. Kim SH, Evans CH, Kim S, Oligino T, Ghivizzani SC, Robbins PD: Gene therapy for established murine collagen induced arthritis by local and systemic adenovirus-mediated delivery of interleukin-4. Arthritis Res 2000, 2:293-302.

30. Apparailly F, Verwaerde C, Jacquet C, Auriault C, Sany J, Jorgensen C: Adenovirus-mediated transfer of viral IL-10 gene inhibits murine collagen-induced arthritis. J Immunol 1998, 160:5213-5220.

31. Kim KN, Watanabe S, Ma Y, Thornton S, Giannini EH, Hirsch R: Viral IL-10 and soluble TNF receptor act synergistically to inhibit collagen-induced arthritis following adenovirus-mediated gene transfer. J Immunol 2000, 164:1576-1581.

32. Kapsenberg ML: Dendritic-cell control of pathogen-driven T-cell polarization. Nat Rev Immunol 2003, 3:984-993.

33. Steinman RM: Dendritic cells and the control of immunity. Nature 1998, 392:245-252.

34. Okunishi K, Dohi M, Nakagome K, Tanaka R, Mizuno S, Matsumoto K, Miyazaki J, Nakamura T, Yamamoto K: A novel role of hepatocyte growth factor as an immune regulator through suppressing dendritic cell function. J Immunol 2005, 175:4745-4753.

35. Bonanno G, Procoli A, Mariotti A, de Ritis DG, Curti A, Danese S, Pessina G, Pandolfi S, Natoni F, Di Febo A, Scambia G, Manfredini R, Salati S, Ferrari S, Pierelli L, Leone G, Lemoli RM: Hepatocyte growth factor favors monocyte differentiation into regulatory interleukin (IL)- $10^{++} \mathrm{IL}-12^{\text {low/neg }}$ accessory cells with dendritic-cell features. Blood 2006, 108:218-227.

36. Okunishi K, Dohi M, Fujio K, Nakagome K, Tabata Y, Okasora T, Seki M, Shibuya M, Imamura M, Harada H, Tanaka R, Yamamoto K: Hepatocyte growth factor significantly suppresses collagen-induced arthritis in mice. $\mathrm{J}$ Immunol 2007, 179:5504-5513.

\section{doi:10.1186/ar4252}

Cite this article as: Tsunemi et al:: Molecular targeting of hepatocyte growth factor by an antagonist, NK4, in the treatment of rheumatoid arthritis. Arthritis Research \& Therapy 2013 15:R75.

\section{Submit your next manuscript to BioMed Central and take full advantage of:}

- Convenient online submission

- Thorough peer review

- No space constraints or color figure charges

- Immediate publication on acceptance

- Inclusion in PubMed, CAS, Scopus and Google Scholar

- Research which is freely available for redistribution

Submit your manuscript at www.biomedcentral.com/submit
C Biomed Central 